\title{
KONSEP BEING PERSPEKTIF FILSAFAT DAN ISLAM
}

\author{
Suhermanto Ja'far \\ Universitas Islam Negeri Sunan Ampel Surabaya, Indonesia \\ E-mail: herman.goevara@gmail.com
}

\begin{abstract}
This article discuss the concept of being in the perspective of existentialism and Islam. The closest similarity to the word "being" is to on (Ancient Greece), as the word of einai, to be (on, onta). For Parmenides, "being" (to on) is one, eternal and unchanging. Gabriel Marcel calls the way the human being with the term être-au-monde, etre in carne, geist-inwelt. Martin Heidegger uses a formula being in the world to characterize human life. Being in the world as a feature of human life, human beings are in the situation. Living in a world of concrete means that there are human relationships with the situation. Sartre said that the real one where there are two, namely: I'etre en soi and I'etre pour Soi. For Sartre, I'etre en soi is the idea that only a concrete phenomenon has ontological status; only something concrete is real. Unlike the being-in-itself, for Sartre the concept of being-for-itself is a state of being that comes with the awareness and self-control. The concept of being (mujûd) by Suhrawardî is a mental concepts (mahfüm) that do not have the type and diferensia. In the illumination philosophy of Suhrawardî, the idea of wujûd can not be separated from nature and depiction of light. The philosophy of wujùd by Mulla Șadrâ stands on three basic principles of fundamental importance. These three principles are as follows: wahdat al-wujüd, tashkîk al-wujüd, and tashkîk. While Mohammad Iqbal emphasis on metaphysics and anthropological philosophy. Iqbal gives greater emphasis on more concrete dimensions, namely khudi (ego).
\end{abstract}

Keywords: The concept of being; existentialism; Islam.

\section{Pendahuluan}

Dalam filsafat Yunani Kuno, manusia dianggap sebagai mikrokosmos_- "dunia kecil" dalam komposisi "dunia besar"—-dari alam semesta. Pandangan filsafat ini bertumpuh dari refleksi dan simbol alam semesta yang dipahami dari eksistensi manusia sebagai 
organisme spiritual. Karenanya, setiap orang akan memahami bahwa dalam dirinya memiliki semua elemen dasar alam semesta. Organisme spiritual sebagai unsur penting dari manusia menurut tradisi agama dikenal dengan jiwa atau roh, sedangkan dalam tradisi filsafat meminjam istilah Aristoteles (384-322 SM) seringkali diidentifikasi sebagai "jiwa yang berpikir" (animale rationale). Organisme spiritual inilah yang membedakannya secara prinsipil dengan makhluk selain manusia. ${ }^{1}$ Awalan ini menunjukkan bahasan tentang eksistensi manusia menjadi objek penting dalam penyelidikan pelbagai disiplin ilmu, termasuk filsafat dan agama.

Eksistensi manusia dipahami sebagai suatu kesatuan organisme dari unsur biologis dan psikologis, atau alam dan sosial. Dalam kehidupannya, eksistensi manusia merupakan perjalanan yang mengikuti aturan-aturan biologi-fisiologis seperti adanya sirkulasi darah, kebutuhan terhadap nutrisi dan oksigen dalam tubuh, serta mengikuti sistem organisme hidup; lahir, dewasa, dan mati. Adapun dari fase eksistensi individual-psikologis, manusia mengalami proses pembentukan emosional sejak usia anak, dewasa hingga tua. Oleh karenanya, manusia disebut sebagai organisme yang memiliki sistem perkembangan paling kompleks dibanding dengan makhluk hidup lainnya. Selain itu, tingkat kecerdasan yang tinggi juga menempatkan manusia sebagai titik pusat dari semua bentuk gerak materi yang ada di alam semesta, sehingga manusia diyakini telah diberkahi oleh tuhan dengan kekuatan dasar dari alam. Ia-manusia—semenjak lahir, eksistensi individualnya dipercaya mempuyai keterhubungan dengan alam semesta. Tidak heran jika manusia disebut sebagai mikrokosmos karena keterwakilan, eksistensi dan keunikannya secara fisiologis dan psikologis sebagai bagian dari makrokosmos.

Socrates dan Plato melangkah lebih mendalam dengan melakukan kajian tentang alam kecil atau dunia kecil (mikrokosmos), yaitu manusia. Socrates (469-399 SM) menyebutkan bahwa tujuan tertinggi manusia adalah pada jiwanya (psikhe) agar menjadi sebaik mungkin. Tingkah laku manusia dapat disebut baik bila manusia dipandang dari psikhe-nya-tidak hanya dari aspek lahiriah-yang mencitrakan ia baik. Pernyataan ini mengantarkan pada simpulan bahwa tujuan hidup manusia adalah eudaimonia (kebahagiaan) yang bersamayam dalam dimensi batinnya, bukan yang tampak dari dimensi lahirnya. Sebab

1 Bruce Aune, Metaphysics the Elements (London: University of Minnesota Press, 1998), 3-5 dan 6-10. 
jika mengacuh filosofi bangsa Yunani, eudaimonia berarti kesempurnaan atau lebih tepat lagi dikatakan bahwa endaimonia berati mempunyai daimon yang baik, dan yang dimaksud dengan daimon adalah jiwa. ${ }^{2}$ Lebih dalam lagi, Socrates menyebutkan, manusia dapat mencapai eudaimonia atau kebahagiaan dengan arete (moral virtue). Arete adalah keutamaan seorang berdasarkan kodrat untuk apa ia dicipta. Seorang negarawan mempunyai arete yang memungkinkannya menjadi politikus yang baik. Seorang tukang sepatu yang mempunyai arete akan menyebabkan ia menjadi seorang tukang sepatu yang baik. Dengan arete keduanya mendapat pengetahuan yang memungkinkannya menjadi seorang politikus atau tukang sepatu yang baik.

Plato (427-347 SM) — salah seorang murid Socrates-menegaskan pandangannya bahwa manusia adalah makhluk yang terpenting diantara semua makhluk yang terdapat di dunia dan sebagaimana juga gurunya, ia menganggap bahwa jiwa sebagai pusat atau intisari kepribadian manusia. Jiwa bersifat kekal dan sudah ada terlebih dahulu sebelum keberadaannya di dunia material dan fana yakni di alam lain yang disebut alam idea (ide). Kelahiran manusia di dunia membuat manusia lupa akan alam ide sebelumnya. Meskipun pengetahuan dari alam ide itu terlupakan oleh manusia sejak ia lahir ke alam fana (dunia), tapi pengetahuan tentangnya tidak hilang sama sekali, pengetahuan tersebut tetap tinggal dalam jiwa manusia dan dapat diingatkan kembali dari proses hidup yang dijalani. Dengan demikian, pengetahuan manusia di dunia pada dasarnya adalah pengenalan kembali atau pengingatan (anamnesis) terhadap alam ide yang dulu pernah dikenalnya. ${ }^{3}$

Socrates dan Plato mencoba memahami manusia dalam kerangka berpikir yang sangat universal. Manusia dipandang oleh keduanya sebagai bagian dari makrokosmos yang disebut mikrokosmos. Sebagaimana manusia yang dipandang terdiri dari tubuh dan jiwa, maka alam semesta juga dipandang secara dualistik sebagai tubuh dan jiwa yang diciptakan oleh "sang tukang" (demiurgos) dalam postulat keduanya. Pada titik ini dapat dimengerti ciri khas dari pemikiran filsafat pada masa Yunani Kuno ketika melihat segala sesuatu sebagai satu kebenaran, maka para filsuf akan memikirkan segala sesuatu itu sebulat-bulatnya (whole), termasuk tentang alam semesta. Cara berpikir

\footnotetext{
2 Ibid., 37.

3 Catalin Partenie dan Tom Rockmore (eds.), Heidegger and Plato toward Dialogue (Evanston, Illinois: Northwestern University Press, 2003), 121-140.
} 
serta pengetahuan yang mendasar dan unversal semacam ini, diwarisi oleh Aristoteles-murid Plato yang hidup pada tahun 384-322 SM dan belajar di akademi milik Plato-yang menguasai sampai mendalam hampir segala ilmu yang diketahui pada masanya. Aristoteles adalah ahli dalam ilmu alam, hukum, etika dan lain-lain. ${ }^{4}$ Namun, antara Guru dan Murid itu terdapat silang pandang tentang hakikat terpisah atau menyatu antara tubuh dan jiwa.

Telah diketahui di era filsafat Yunani Kuno ketertarikan filsuf terhadap alam lebih dominan daripada keingintahuan terhadap manusia, sehingga permasalahan tentang manusia yang kompleks belum dapat terpecahkan secara tuntas, melainkan hanya berkutat pada persoalan tubuh dan jiwa yang terdapat dalam diri manusia. Teori dualisme Plato tetap tidak memberikan pengaruh besar terhadap filsuf setelahnya mengenai pembahasan tentang manusia. Demikian juga dengan Aristoteles yang memandang manusia serupa dengan entitas-entitas lain yang hidup di kosmos. Perenungan Aristoteles berhasil menetapkan kesatuan badan dan jiwamonisme-yang menurut pandangan ini struktur kodrat manusia mirip entitas-entitas lainnya di dunia, sehingga jiwa manusia pun harus diakui sebagai morphe (bentuk atau rupa). Namun demikan, tetap saja ujungnya Aristoteles terjebak dalam pemahaman dualistik, meski tidak serupa dengan dualisme Plato. Pada akhirnya, teori keduanya masih belum memberikan solusi bagi persoalan kedirian manusia dalam kehidupan sehari-hari.

Setelah masa Aristoteles, terjadi peralihan corak pemikiran filsafat Yunani menjadi filsafat Helen-Romawi terutama disebabkan oleh perluasan wilayah kerajaan Romawi pada masa Alexander Agung (356323 SM), salah seorang murid dari Aristoteles. Dengan makin meluasnya wilayah kerajaan Romawi, keinginan menguasai pengetahuan teoretis makin beralih kepada ilmu-ilmu khusus yang lebih berguna bagi kehidupan faktual kala itu. Kepercayaan rakyat pada agama semakin menyusut, sehingga orang makin mencari hasil praktis yang bernilai guna untuk meningkatkan kesenangan hidup sebagai akibat perbudakan dan kondisi sosial yang menekan. Ilmu yang berkembang pada masa itu adalah etika, suatu ajaran tentang martabat hidup di dunia, maupun pengetahuan khusus yang sifatnya praktis. Dalam

${ }^{4}$ Ibid. 
periode ini berdirilah sekolah yang didirikan oleh Epikuros (341217SM)..$^{5}$

Berlainan dengan Aristoteles, Epikuros tidak mempunyai perhatian terhadap penyelidikan ilmiah. Ia hanya mempergunakan pengetahuan yang diperolehnya sebagai alat membebaskan manusia dari ketakutan agama, yaitu rasa takut terhadap dewa-dewa yang ditanam dalam diri manusia oleh agama Yunani Kuno. Menurutnya, ketakutan akan dewa-dewa yang menjadi penghalang besar untuk memperoleh kesenangan hidup. Ia mengembangkan fisika praktis untuk membebaskan manusia dari kepercayaan akan dewa-dewa. Ia mencoba menjelaskan bahwa segala yang terjadi bersifat kausalitasmekanis. Tidak perlu dewa-dewa diikut sertakan dalam peredaran alam. Semenjak berakhirnya periode Aristoteles, dapat dikatakan filsafat Yunani kehilangan masa keemasannya dan jatuh pada penelaahan yang sifatnya spasial dan kehilangan sifat penelaahan yang mendasar ${ }^{6}$ sebagaimana yang dirintis oleh Epikuros. Refleksi masa lalu ini mengawali untuk memberi perbandingan perspektif menurut filsafat dan Islam tentang menjadi manusia yang selalu direnungkan oleh dirinya sendiri hingga saat ini.

\section{Problem Filosofis Eksistensi Manusia}

Problematika manusia tidak akan lepas dari eksistensinya, karena manusia menempati bumi dantidak memisahkan diri dari entitas di luar dirinya. Oleh karenanya, manusia sebagai being mestinya dilihat dari awal eksistensi manusia semenjak dalam kandungan dan dilahirkan sampai mencapai kematangan dan mati sebagai makhluk hidup. Sebagai individu, eksistensi manusia ditandai oleh bentuk tertentu dari organisme tubuhnya yang mampu berfungsi melalui interaksi yang kompleks dari proses kimia dan fisika. Selain itu manusia juga ditentukan oleh kecenderungan dan lingkungan, di mana setiap individu berbeda dan memiliki kekhasan dari individu lain. Jika dibandingkan dengan entitas lain di makrokosmos, maka eksistensi manusia berbeda dari hewan dan makhluk hidup lain, karena adanya dimensi kesadaran (conciousness) manusia. Ini perbedaan kualitatif antara manusia dan makhluk hidup lainnya yang mencirikan sifat hidup manusia secara khusus dan khas jika dipandang dari eksistensinya.

5 James Warren, Facing Death: Epicurus and his Critics (Oxford: Clarendon Press, 2004), 162-165.

${ }^{6}$ Ibid. 
Para filsuf dari aliran eksistensialisme pun tidak pernah memberikan arti yang tepat tentang pemakaian istilah existence, namun terdapat arti pokok yang menjadi dasar aliran eksistensialisme untuk memahami eksistensi manusia, bahwa manusia dapat menemukan eksistensinya dengan keluar dari dirinya sendiri. Eks berarti keluar, sistensi berarti berdiri, jadi ber-eksistensi berarti berdiri sebagai diri sendiri dengan keluar dari diri sendiri. Ber-eksistensi berarti mengarah pada dunia luar atau yang lain. Dengan kata lain eksistensi adalah cara manusia berada di dunia atau eksistensi hadir di dunia dan mengarah pada sesama dan Tuhan. Secara etimologis, eksistensialisme berasal dari kata Inggris existence, dari bahasa Latin existere (muncul, ada, timbul, memiliki keberadaan aktual), dari ex (keluar) dan sistere (tampil). ${ }^{7}$ Sedangkan eksistensialisme merupakan gerakan filsafat penentang esensialisme. Pusat perhatiannya adalah situasi manusia. Eksistensialisme adalah filsafat yang memandang segala gejala dengan berpangkal pada eksistensi. Pandangan ini relatif modern dalam filsafat, walaupun akar-akar historis sudah ada dalam filsafat Yunani dan filsafat Abad Pertengahan. Filsafat ini menyatakan eksistensi bukan objek dari berpikir abstrak atau pengalaman kognitif (akal pikiran), tetapi merupakan eksistensi atau pengalaman langsung, bersifat pribadi dan dalam batin individu.

Filsafat eksistensialisme ini bertujuan menjawab pertanyaan bagaimana manusia seharusnya hidup sesudah ilusi tentang kebebasannya hancur berantakan oleh malapetaka yang begitu banyak dalam sejarah. Bencana historis menghancurkan ilusi tentang kebebasan manusia, dan eksistensialisme juga bertujuan sebagai perlawanan terhadap pandangan yang menempatkan manusia pada tingkat impersonal atau abstrak. Ini berarti eksistensialisme menganjurkan manusia membentuk dirinya dengan tindakannya

\footnotetext{
7 William Barret mengatakan bahwa eksistensialisme adalah filsafat yang berhadapan dengan keberadaan manusia dan bagaimana manusia dapat berdiri/berada dalam kondisi itu. Untuk lebih jelasnya baca Nino Langiulli, The Existentialist Tradition (USA: Yhe Anchor Books, 1971), 4. Sementara itu, H.J. Blackman menggarisbawahi bahwa Eksistensialisme adalah suatu filsafat keberadaan, suatu filsafat pembenaran dan penerimaan yang abstrak tentang kebenaran. Lihat H.J. Blackman, Six Existentialist Thinkers (London: Routledge dan Kegan Paul, 1952), 149. Pada dasarnya eksistensialisme adalah filsafat yang banyak membicarakan tentang keberadaan manusia. Bandingkan Jan Hendrik Rapar, Pengantar Filsafat (Yogyakarta: Kanisius, 1996), 116. Bandingkan Henryk Misiak dan Virginia Staudt Sexton, Psikologi Fenomenologi, Eksistensial, dan Humanistik (Bandung: Refika Aditama, 2005), 80.
} 
sendiri. ${ }^{8}$ Seorang manusia bebas mengambil tanggung jawab atas apa yang telah diperbuatnya, dan tidak menggantungkan diri berdasarkan hal-hal di sekitarnya. Karena itu, manusia bertanggung jawab atas sesuatu yang telah menjadi pilihan hidupnya.

Makhluk yang bernama manusia merupakan makhluk kompleks yang terdiri dari berjuta-juta protoplasma. Namun apa itu protoplasma? Protoplasma adalah suatu makhluk yang terdiri dari materi-materi yang tak berkesadaran. Dengan suatu proses yang menakjubkan, protoplasma berubah menjadi makhluk hidup. Protoplasma merupakan "kesatuan biologis". Namun, manusia tidak dapat mempelajari "kesatuan biologis" ini dengan cara dan metodemetode yang dipergunakan dalam mempelajari alam material. Dengan kata lain, perubahan dari protoplasma menjadi makhluk hidup ini merupakan hal yang unik dan penuh misteri pada kehidupan manusia.

Keunikan dan kemisterian manusia dari kompleksitas yang menjadi "rebutan" penyelidikan para ahli di bidangnya masing-masing tetap tidak bisa menembus "rahasia" unik manusia. Hal ini dikarenakan, manusia terlampau pelik untuk diketahui, kendatipun manusia mampu mengetahui apapun. Dalam diri manusia, tidaklah hanya organisme benda-benda yang mati berasal dari tanah dan air yang hina, tetapi manusia juga mempunyai kekuatan-kekuatan hidup, kesadaran dan penyadaran diri. Manusia itu sendiri merupakan evolusi eksistensial yang berproses secara spontan dan terencana. Kekuatan-kekuatan hidup manusia merupakan hubungan dari materi, tumbuh-tumbuhan dan hewan. Eksistensi dalam dunia jasad manusia hanya dapat dicapai oleh makhluk-makhluk tiga dimensi. ${ }^{9}$

Tiga dimensi manusia tersebut, yaitu yang punya hidup, kesadaran dan penyadaran diri. Berbeda dengan manusia, hewan yang memiliki dua dimensi, hidup dan kesadaran hanya bereksistensi seperti bayangan. Apalagi tumbuhan yang hanya memiliki hidup yang pasif saja. Manusia sebagai puncak tertinggi evolusi eksistensial banyak menyimpan hal-hal yang pelik. Hanyalah manusia yang mempunyai eksistensi sejati di dunia ini. ${ }^{10}$

${ }^{8}$ Hans Bernhard Schmid, Plural Action Essays in Philosophy and Social Science (London New York: Springer Dordrecht Heidelberg, 2008), 2-26; 133-137; 167-172 dan 215240.

9 Suhermanto Ja'far, Orientasi Baru Filsafat Manusia menurut Islam (Surabaya: LP2M UINSA, 2014), 29-51.

${ }^{10}$ E.F. Schumacher, Keluar dari Kemelut: Sebuah Peta Pemikiran Baru (Jakarta: LP3ES, 1988), 17-29. 
Dalam kajian eksistensialisme, manusiapun tetap menjadi makhluk yang unik. Sartre, tokoh eksistensialis mendefinisikan manusia sebagai makhluk yang unik di atas alam, karena manusia mempunyai susunan yang istimewa dan berbeda dengan makhluk lainnya dalam alam. Menurut Sartre, manusia adalah satu-satunya makhluk di alam semesta yang eksistensinya mendahului esensinya. Alasan Sartre menganggap manusia sebagai suatu makhluk unik di atas alam, karena manusia dituntut untuk mampu menentukan nasibnya sendiri di dunia. ${ }^{11}$

Manusia sebagai eksistensi merupakan struktur dasar "ada"nya manusia yang tidak bisa didekati secara biologis maupun fisiologis. Ini karena eksistensi berbicara mengenai status ontologi manusia. Status ontologis di sini titik tekannya pada hakikat keberadaan manusia sebagai makhluk yang keberadaannya tidak sama dengan makhlukmakhluk lain. Manusia sadar dan memahami akan eksistensinya, sedangkan makhluk-makhluk selain manusia tidak sadar dalam memahami eksistensinya. Kesadaran manusia akan eksistensinya, tidaknya hanya untuk dirinya, tetapi juga untuk sesama maupun Tuhan. Di sinilah kesadaran intensionalitas manusia dengan lainnya merupakan problem metafisika yang membutuhkan abstaksi tingkat tinggi. ${ }^{12}$

\section{Konsep Being menurut Eksistensialisme}

Masalah being adalah masalah utama dan mendasar dalam filsafat. Problem utama adalah masalah definisi, apa yang dimaksud being? Dalam sejarah filsafat telah banyak argumen-argumen yang mencoba mencari solusi untuk mengembangkan filsafat being. Yang terdekat kesamaannya dengan kata being adalah to on (Yunani Kuno), sebagai kata dari einai, to be (on, onta). Kata itu dipakai sebagai bagian pertama dari puisi Parmenides yang memiliki fokus pada kata esti, bentuk tunggal orang ketiga dari einai dan eon, yang setara dengan to on dalam dialek Parmenides. Bagi Parmenides, being (to on) adalah satu, abadi dan tidak berubah. Ini adalah kebenaran. Semua berbicara tentang pluralitas dan perubahan adalah "pendapat" (doxa), dan bukan kebenaran tentang being itu sendiri. ${ }^{13}$

11 Jean-Paul Sartre, Being and Nothingness (New York: Simon dan Schuster, 1992), 73. 12 Ja'far, Orientasi Baru Filsafat Manusia, 53-54.

13 Perkembangan sistematis konsep being dalam filsafat Yunani berasal dari Parmenides dan Aristoteles. Kemudian mengalami perubahan dengan cara yang lebih mekanis dari Stoa ke Plotinus. Konsep being sesungguhnya mempunyai padanan kata kerja einai. Pemaknaan ini bergantung pada disposisi yang sudah ada sebelumnya dari bahasa yang sangat umum dan beragam dalam bahasa Yunani. 
Dengan meminjam istilah Gabriel Marcel, tokoh eksistensialis, ${ }^{14}$ maka cara manusia itu berada dapat disebut etre-au-monde-being in the world (ada di dunia), etre in carne (ada yang mendaging), geist-in-welt (Roh di dunia. Manusia, untuk benar-benar menjadi manusia haruslah memanusiakan dirinya sendiri. ${ }^{15}$ Gabriel Marcel melihat kata mempunyai dan ada tentang tubuh merupakan satu kesatuan hakiki. Kata mempunyai menunjuk pada relasi kepemilikan, berkenaan dengan benda atau sifat, sedangkan kata ada mengungkap identitas atau persamaan dan tidak ada pemisahan dan pertentangan antara subjek dan objek. Manusia adalah tubuh dan mempunyai tubuh. Artinya, manusia mempunyai sekaligus adalah tubuhnya itu sendiri. ${ }^{16}$

\section{Heidegger: Being in the World}

Martin Heidegger memakai rumusan being in the world (ada-dalamdunia) untuk mencirikan hidup manusia. Being in the world sebagai ciri hidup manusia, maka manusia berada dalam situasi, sehingga manusia benar-benar hidup secara konkret dalam dunia. Hidup dalam dunia konkret berarti terdapat keberkaitan manusia dengan situasi.

Selanjutnya, sejauh gagasan yang diungkapkan oleh on, einai, dan ousia dalam bahasa Yunani mendasari doktrin being, substansi, esensi, dan eksistensi dalam bahasa Latin. Berdasarkan hal ini, maka penggunaan kata kerja Yunani di sini membentuk dasar sejarah bagi tradisi filsafat Barat, sebagai "ontologi” Untuk lebih jelasnya, lihat Anthony Preus, Historical Dictionary of Ancient Greek Pbilosophy (Lanham: Scarecow Press, 2007), 66-69.

${ }^{14}$ Eksistensi adalah seluruh kompleks yang meliputi semua faktor konkret, hal ini dari peristiwa hidup yang digumuli secara pribadi oleh Marcel. Eksistensi tidak lebih penting dari esensi atau objektivitas, dan hal ini dapat dialami dan bermakna ketika manusia memiliki relasi dengan manusia lain. Peralihan itu memiliki tiga fase; admiration atau kekaguman, reflextion atau perenungan dan exploration atau eksplorasi. Gabriel Marcel, The Mystery of Being Volume I: Reflection and Mystery (London: The Harvill Press, 1950), 125-130.

${ }^{15}$ Keberadaan manusia di dunia (etre-au-monde) menurut Gabriel Marcel ini tidaklah terlepas dari keberadaan alam materi. Artinya, alam materi sebagai wadah roh di dunia (geist-in-welt). Manusia tidaklah dipandang sebagai ada yang tidak dapat ditangkap oleh indra, tapi manusia dipandang dari satu sudut ada-nya sebagai barang di dunia. In-welt (di dunia) dan kenyataannya menunjukkan manusia berada di dunia tidak hanya rohaniah semata, melainkan betul-betul sebagai barang duniawi. Ia melekat di dunia ini, bersatu dengan barang-barang lainnya. Pada akhirnya terbentuklah apa yang dikatakan Roh menjelma pada daging. Lihat Gabriel Marcel, The Mystery of Being Volume II: Faith and Reality (London: The Harvill Press, 1951), 130.

16 Gabriel Marcel, Being and Having, terj. Katharine Farrer (Glasglow: University Press, 1949), 9-14 dan 26-30. 
Keberkaitan dengan situasi menunjukkan bahwa hidup manusia selalu dinamis. Dinamisitas ini menunjukkan bahwa manusia hidup tidak hanya ke dalam tetapi juga ke luar.

Menurut Heidegger kesalahan dari tradisi filsafat Barat yakni menerima begitu saja pemahaman yang miskin tentang makna 'ada' (being). ${ }^{17}$ Ada dipandang sebagai kenyataan yang hadir terlepas dari subjek manusia. Konsep ini bertahan mulai dari Plato sampai Descartes. Heidegger dalam karya Ada dan Waktu membahas ada dalam kaitannya dengan waktu. Dalam hidup sehari-hari, manusia bergelut dengan ada. Manusia satu-satunya makhluk yang dibimbing oleh suatu pengetahuan yang samar tentang "ada". Manusia adalah ada yang unik. Keunikannya mampu membedakannya dengan bendabenda dan membuatnya mampu mempersoalkan 'ada'. Karena manusia bukan benda, maka Heidegger memilih istilah dasein untuk menunjukkan "ada" manusia. Pemikiran Heidegger berporos pada suatu distingsi yang disebut pembedaan ontologi, yakni antara sein (ada) dan seinde (mengada). ${ }^{18}$ Heidegger dalam menangani masalah ontologi menggunakan metode fenomenologi yang diterapkan dalam melihat ke-disana-annya dasein yakni kelahirannya di dunia ini. Namun kelahirannya ini juga masih belum asli betul, karena masih bersifat biologis dan belum ontologis. ${ }^{19}$

Ada dalam dunia merupakan struktur dasein. Dunia bukan sesuatu yang tergeletak terpisah dari dasein. Heidegger memperjelas gagasannya tentang dunia dengan membagi empat jenis dunia.

${ }^{17}$ F. Budi Hardiman, Heidegger dan Mistik Keseharian: Suatu Pengantar Menuju Sein und Zeit (Jakarta: KPG Kepustakan Populer Gramedia, 2003), 31-45.

${ }^{18}$ Mengada atau seinde hanya berlaku pada benda-benda yang bukan manusia yang jikalau dipandang pada dirinya sendiri artinya: terpisah dari segala yang lain, hanya berdiri sendiri. Manusia sebenarnya juga berdiri sendiri, namun manusia dapat menanyakan ada karena memiliki hubungan dengan ada-nya. Tidak seperti mengada-mengada lain yang tidak sadar akan ada-nya. Hubungan dengan adanya itu yang disebut eksistensi. Eksistensi manusia atau dasein berbeda dengan benda-benda. Benda-benda tidak bisa mengambil jarak dengan keberadaannya, sedangkan manusia dapat mengambil jarak dan mempersoalkan. Menurut Heidegger, Dasein adalah benda-benda mengada dalam sang dunia (being-in-the-world) yang ditegaskan Heidegger di sini merupakan suatu "fenomena kesatuan" (unitary phenomenon). Artinya, "ada" dasein dan dunia tidak terpisah dan berhadapan satu sama lain. Heidegger, Being and Time, 78. Sedangkan dalam buku lain arti kata sein dan seinde diartikan dengan "berada" untuk sein dan "yang berada" untuk seinde. Lihat Harun Hadiwijono, Sari Sejarah Filsafat Barat 2 (Yogyakarta: Kanisius, 2002), 150.

${ }_{19}$ Maurice Natanson, Phenomenology and the Social Sciences (London: North-Western: University Press, 1973), 6. 
Pertama, pengertian dunia secara ontis: dunia dipahami sebagai totalitas objek-objek deskriptif. Kedua, pengertian dunia secara ontologis: dunia sebagai ranah yang meliputi beraneka ragam benda-benda. Ketiga, pengertian dunia secara ontis-existential: dunia bukan sebagai kumpulan benda-benda yang berbeda dengan dasein, melainkan tempat dasein secara historis bertempat. Makna dunia di sini bisa berupa dunia bersama yang bersifat publik maupun dunia privat-domestik. Keempat, pengertian dunia secara ontologis-existential: dunia yang meliputi dasein yang tidak tergeletak begitu saja, melainkan mempengaruhi dan dipengaruhi oleh dasein. Bahasa Heidegger, dasein tidak sekadar hadir di dalam dunia, tetapi ia 'mendunia'. ${ }^{20}$

Keberadaan dasein dengan orang lain ini merupakan salah satu cara berada dasein di dunia dan bukan sesuatu yang bersifat kebetulan atau diletakkan begitu saja. Kita mengenal ada tidak hanya melalui diri kita sendiri, melainkan juga melalui ada orang-orang lain, seperti yang ditulis Heidegger, "Atas dasar ada-di-dalam-dunia secara bersama ini, dunia sudah selalu merupakan dunia yang aku mukimi bersama dengan orang lain". Dunia dasein adalah dunia-bersama. Ada-di-dalam adalah ada-bersama orang lain. ${ }^{21}$

Perkembangan tentang in-otentisitas membawa kita pada tiga karakteristik dasein yang cukup dominan, yakni faktisitas (state of mind), pemahaman (understanding), dan kejatuhan (fallness). Faktisitas sebagaimana telah diuraikan sebelumnya merupakan karakter dasein yang terlempar ke suatu dunia yang menentukan kebermaknaan benda-benda. Keberadaan dasein di dunia ini adalah suatu faktisitas niscaya yang tak mampu mempunyai alasan. ${ }^{22}$ Karakter yang kedua dari ada-nya dasein adalah pemahaman (understanding). Dalam pemahaman ini dasein sebagai yang ada-di dalam-dunia mencoba memahami keterlemparan, ia sadar bahwa di hadapannya terbentang segala kemungkinan-kemungkinan untuk bertindak. Ada dasein adalah menjadi, karena terus menerus mengada. ${ }^{23}$

\footnotetext{
${ }^{20}$ Donny Gahral Adian, Martin Heidegger (Jakarta: Teraju, 2003), 27-28.

${ }^{21}$ Heidegger, Being and Time, 147.

22 Facticity is not the factually of the factum brutum of something presen-of-hand, but a characteristic of Dasein's Being-On which has been taking up into existence, even if proximally it has been thrust a side. Ibid., 174.

${ }^{23}$ In understanding, as an existentiale, that which we have such competence over is not a "what", being as existing. The kind of being which Dasein has, as potentiality-for-being, lies existentially in understanding. Ibid., 183-185.
} 
Heidegger mensistesiskan pengertian di atas ke dalam satu istilah, yakni: "melampaui dirinya dan sudah ada-di dalam-dunia sebagai adabersama-yang lain". ${ }^{24}$ Heidegger memberi penjelasan bahwa dasein menemukan keterlemparan dirinya dalam dunia dan ia bergumul dengan benda-benda dan manusia lainnya. Melampaui dirinya berarti menemukan diri terlempar dan berusaha mengantisipasi masa depan. Ada di dalam dunia merupakan keterlemparan yang bersifat faktis. Ada bersama yang lain menyebabkan hanyut dalam kesibukan seharihari dan inilah kejatuhan dasein. Keterlemparan (faktisitas) dan hanyut dalam kesibukan sehari-hari (kejatuhan) oleh Heidegger disebut dengan sorge.

Beberapa filsuf sebelum Heidegger juga mendefinisikan waktu, misalnya, Aristoteles mendefinisikan waktu sebagai "perhitungan gerak menurut yang dulu dan yang kelak" (numerus motus secundum prius et posterius). Menurut Husserl, waktu termasuk inti pengalaman manusia. Dalam pengalaman tentang suatu hal yang saat ini, manusia sadar juga tentang apa yang terjadi pada waktu yang lampau dan tentang apa yang akan terjadi pada waktu yang akan datang. ${ }^{25}$ Bagi Heidegger waktu adalah tahap-tahap eksistensi yang tidak dapat dipisahkan antara masa lalu, sekarang dan yang akan datang (masa depan). Waktu yang dibicarakan Heidegger bukanlah fenomena psikis belaka, akan tetapi menyangkut struktur-struktur ada manusia sehingga bersifat eksistensial, menyangkut ada dasein. Waktu yang mengikatkan eksistensi personal kepada keseluruhan. Menurutnya, seseorang tidak hanya yang ada dalam waktu tetapi sebuah wujud temporal, yaitu wujud dengan masa lalu, sekarang dan masa depan yang dalam interaksi dan rekreasi terus menerus hendak menetapkan eksistensi personal.

Waktu adalah dimensi eksistensi yang memungkinkan dasein menuju ada-nya sendiri, menuju eksistensinya sendiri. Waktu juga merupakan arah gerak perubahan kehidupan dasein, lebih dari sekadar ilustrasi di atas bila kita mengamati gerak perubahan tersebut Dasein yang terlempar ke dunia dan larut dalam rutinitas keseharian bersama meng-ada-meng-ada lainnya serta memiliki kemungkinankemungkinannya adalah gerak perubahan waktu yang terjadi pada masa lalu, sekarang dan yang akan datang. Heidegger juga memberi pembedaan atas struktur kemewaktuan dasein. Dulu, kini, dan nanti

\footnotetext{
24 Ibid., 236.

25 Theo Huijbers, Manusia Merenungkan Dirinya (Yogyakarta: Kanisius, 1987), 162.
} 
dalam momen-momen kemewaktuan dan gerak eksistensial yang oleh Heidegger disebut "ekstasis waktu". Ekstasis waktu merupakan gerak eksistensial yang melampaui dirinya dapat kita simpulkan menjadi masa lalu ditarik melampaui dirinya ke masa depan, demikian halnya masa kini mengarah ke depan. Singkatnya kita tidak boleh memahami ekstasis-ekstasis waktu (lalu, kini, dan nanti) sebagai sekuensi atau yang satu setelah yang lain. Masa lalu tidak lebih dahulu dari masa kini dan masa depan tidak lebih kemudian dari masa kini. ${ }^{26}$ Keberadaan di dunia merupakan proses "menjadi manusia". "menjadi manusia secara fundamental berarti mengada (to exist)" ${ }^{27}$ Mengada berarti "keluar" (stand out) sebagai yang unik dan khas yang selalu milik-ku dan yang mengekspresikan diri melalui kata-ganti personal "aku". ${ }^{28}$ Kedirian manusia sangat ditentukan dalam konteks keterlibatannya dalam dunia. Ia menghadirkan dirinya hanya dalam kaitannya dengan dunia. Cara berada manusia tidak dapat digambarkan tanpa keterkaitan dengan dunia. ${ }^{29}$

Kesadaran merupakan suatu aktivitas. Tidak ada dunia-padadirinya yang lepas dari kesadaran. ${ }^{30}$ Asumsi di atas menunjukkan bahwa tidak ada selubung yang memisahkan subjek dengan objek. Realitas tampil pada kesadaran. Hal ini dapat terjadi karena kodrat kesadaran adalah terarah pada realitas. Sesungguhnya tidak ada apa yang disebut dengan dunia ontologis yang terpilah dari subjek. Tidak ada pula suatu subjektivitas murni yang lepas dari dunia. "Keterlibatan", dengan demikian, merupakan cara berada manusia-didalam-dunia. ${ }^{31}$ Berada dalam dunia berarti manusia "mengada". Manusia tidak berarti hanya ada dalam dunia, tetapi juga ada "pada" dunia. Unsur "pada" menunjukkan suatu jenis karakter yang dinamis. Pada akhirnya, posisi dunia yang menjadi tempat manusia berada juga bermakna eksistensial, karena menjadi tempat seseorang menjalani

\footnotetext{
${ }^{26}$ John Van Buren, Martin Heidegger: From the Earliest Essays to Being and Time and Beyond (New York: State University of New York Press, 1993), 39-61 dan 111-147.

${ }^{27}$ WA. Luijpen, Existential Phenomenology (New York: Duquesne Univ. Press, 1960), 18-19.

28 John Macquarrie, Martin Heidegger (London: Lutterworth Press, 1980), 17.

${ }^{29}$ Buren, Martin Heidegger, 71-75.

${ }^{30}$ Karlina Leksono-Supeli, Aku dalam Semesta: Suatu Kajian Filsafat atas Hubungan Subjek-Objek di dalam Kosmologi (Disertasi--Pascasarjana Universitas Indonesia Jakarta, 1994)), 45.

${ }^{31}$ Ibid., 42.
} 
kehidupannya. Artinya, dunia adalah sekitarku yang tidak berada di sana begitu saja, tetapi dipengaruhi dan mempengaruhi aku. ${ }^{32}$

2. Sartre: etre-en-soi dan etre-pour-soi

Eksistensialisme Sartre menyatakan bahwa eksistensi mendahului esensi. Ia hanya menyatakan bahwa manusia sebagai makhluk hanya berada di bumi dengan menentukan dirinya sendiri melalui hidup, sementara objek-objek (benda-benda) ada dengan sendirinya sampai hancur tanpa disadari. Sartre memberikan makna bahwa "manusia sebagai dirinya sendiri" adalah pertama tubuh, maka esensi didefinisikan melalui tindakan. Sebaliknya, Sartre dalam konteks ini menyatakan bahwa tidak ada kodrat manusia yang bisa dipandang sebagai asasi. manusia ada sejauh dia menyadari dirinya. Sartre mengatakan bahwa sesunggunya suatu keberadaan itu ada dua, yakni: I'etre en soi, berada dalam diri. Yang kedua adalah I'etre pour Soi, yaitu berada untuk diri. Berada dalam diri ini merupakan keberadaan suatu benda, sedangkan keberadaan untuk diri adalah seperti keberadaannya manusia. Dalam keberadaan untuk diri, sesuatu itu mempunyai kesadaran akan keberadaannya. Being-in-itself bagi Sartre merupakan gagasan bahwa hanya fenomena konkret memiliki status ontologis, hanya sesuatu yang konkret adalah nyata. Ia menyatakan bahwa batu adalah batu dan tidak dapat berubah. Dengan cara ini, Sartre menunjukkan ada faktisitas dalam keberadaan objek. ${ }^{33}$

Berbeda dengan being-in-itself, bagi Sartre konsep being-for-itself merupakan keadaan diri yang hadir dengan kesadaran dan kontrol diri. Walter Kaufmann menjelaskan perbedaan tersebut bahwa pour-soi foritself) adalah being yang sadar akan dirinya sendiri dan itu hanya ada pada manusia. Struktur maknanya berbeda dari en-soi, yang hanya merupakan fenomena diri yang palsu. I'etre-pour-soi adalah berada dengan sadar akan dirinya. Keberadaan jenis kedua ini berbeda dengan I'etre-en-soi. Pada keberadaan kedua ini, sesuatu yang berada (manusia) mempunyai hubungan dengan karakter keberadaannya, ia harus bertanggung jawab atas fakta bahwa ia ada. Menurut Sartre, kesadaran yang ada pada menusia itu merupakan kesadaran diri, bukan kesadaran akan diri. Dalam kesadaran akan diri ini selalu ada

32 Leksono-Supeli, Aku dalam Semesta, 63-65.

${ }^{33}$ Jean-Paul Sartre, Existentialism and Human Emotion (New York: Castle, 1948), 4650 . 
jarak antara kesadaran dengan diri itu sendiri, yang selanjutnya kesadaran ini di sebut Sartre dengan ketiadaan (le neant)..$^{34}$

Manusia sebagai mahluk yang berada untuk diri, maka manusia terwujud karena "berada"itu meniadakan diri sebagai manusia. Jadi sebenarnya keberadaan manusia untuk diri ini terdiri dari suatu peniadaan Kesadaran akan katiadaan dirinya, membuat manusia terus berusaha, berbuat dalam rangka untuk menguatkan eksistensinya. Dalam melakukan sesuatu untuk memperjelas eksistensinya, manusia mempunyai kebebasan untuk memilih dan memilah apa yang akan dia lakukan. Sartre mengatakan kalau pada hakikatnya eksistensi manusia adalah kebebasan. Ia dipengaruhi oleh fenomenologi yang menekankan bahwa kesadaran selalu merupakan kesadaran intensional. ${ }^{35}$ Dunia dapat dipahami karena adanya kesadaran. Kesadaran dapat memaknai dunia meskipun kesadaran tidak menciptakan dunia. Bagi Sartre, "menjadi manusia, tidak lain adalah suatu anugerah, suatu berkah yang luar biasa, hanya jika manusia itu sendiri mengakui kebebasan dan mempunyai pertanggung jawaban yang menyeluruh". ${ }^{36}$

\section{Being dalam Konsep Islam}

Dalam Islam konsep tentang being berkaitan dengan teori wujud, baik menyangkut konsep wajiib al-wijûd maupun mumkin al-wujûd. Konsep being (wrijud) menurut Suhrawardî al-Maqtûl merupakan konsep-konsep mental (mahfüm) yang tidak mempunyai jenis dan diferensia. Pembicaraan tentang wujud membawa Suhrawardî ke dalam diskusi tentang wujud niscaya. Menurutnya, segala sesuatu yang mungkin membutuhkan sebab dan seluruh rangkaian entitas yang mungkin di dunia ini membutuhkan sebuah sebab seperti itu, yang mustahil, karena ia harus membentuk rangkaian itu dan dirinya sendiri akan membutuhkan sebuah sebab lain, begitu seterusnya tanpa

\footnotetext{
34 Walter Kaufmann, Existentialism from Dostoevsky to Sartre (New York: Meridian, 1975), 42-43 dan 47-48.

35 John FX. Knasas, Being and Some Twentieth-century Thomists (New York: Fordham University Press, 2003), 93-129.

36 Eksistensi manusia bagi Sartre adalah kebebasan,sebagai sesuatu yang berada untuk diri manusia. Adanya kebebasan menimbulkan suatu hal yang paradoks dan kontroversi. Manusia bebas, tapi terikat. Menurut Sartre, dalam diri manusia itu banyak konflik yang tak akan pernah terdamaikan. Kebebasan dan keterterikatan manusia selalu mempunyai intensionalitas pada yang lain. Sartre, Being and Nothingness, 107-129.
} 
batas. $^{37}$ Wujud yang niscaya adalah sedemikian rupa sehingga jika sesuatu yang termasuk di dalamnya diandaikan tidak ada. Kemustahilan yang muncul, sedangkan wujud yang mungkin adalah sedemikian rupa sehingga jika sesuatu yang termasuk didalamnya diasumsikan tidak ada atau ada, dan tidak ada kemustahilan yang muncul. ${ }^{38}$

Dalam filsafat iluminasi Suhrawardî, gagasan tentang wujud tidak bisa dilepaskan dari sifat dan penggambaran cahaya. Bagian tertingginya adalah cahaya diatas cahaya, yang menjadi sumber eksistensi semua cahaya yang berada di bawahnya, baik yang bersifat murni maupun campuran. Serangkaian cahaya tersebut oleh Suhrawardî juga disebut cahaya mandiri, cahaya suci atau wâjib al-wujûd dan sebagainya. ${ }^{39}$ Bagi Suhrawardî, selain bersifat mandiri, cahaya di atas cahaya ini juga bersifat tunggal. Cahaya adalah suatu esensi yang tidak memerlukan definisi, ia merupakan suatu yang amat nyata pada dirinya, sehingga cahaya itu ada. Suhrawardî menyebut realitas absolut dengan esensi yang tidak terhingga dan tak terbatas, yang disebut dengan cahaya segala cahaya (nûr al-anwâr). Bagi Suhrawardî, nûr alanwâr ini merupakan sumber munculnya wujud-wujud lain, dan memberikan kehidupan kepada wujud-wujud itu dengan sinarnya. Segala sesuatu yang ada di dunia ini berasal dari cahaya esensi-Nya dan semua keindahan serta kesempurnaan adalah pemberian kemurahan-Nya dan benar-benar iluminasi ini berarti keselamatan.

Gagasan tentang wujud yang lebih bernuansa eksistensialis muncul pada gagasan Ṣadr al-Dîn al-Shîrâzî atau yang popular dengan sebutan Mullâ Șadrâ. Pemikiran Ṣadrâ mengenai wujud atau ada dalam tradisi filsafat Barat disebut being. Di sini ada korelasi dengan pembahasan Heidegger melalui karyanya Being and Time. Heidegger melakukan investigasi atau penyelidikan mengenai being atau wujud ${ }^{40}$ Bagi Șadrâ, wujud universal yang abstrak hanyalah gambaran mental saja (itibâr 'aqli). Wujud yang otentik terdapat pada wujud yang konkret (al-wujûd

\footnotetext{
${ }^{37}$ Ibid.

38 Sayyed Hosein Nasr dan Oliver Leaman (eds.), Ensiklopedi Tematis Filsafat Islam, terj. Tim Penerjemah Mizan (Bandung: Mizan, 2003), 299.

39 Majid Fahry, Sejarah Filsafat Islam: Sebuah Peta Kronologis (Bandung: Mizan, 2001), 131.

40 It has been mantained that Being is the 'the most universal' concept. An understanding of Being is already included in conceiving anything which one apprehends in entities. Heidegger, Being and Time, 22.
} 
al-'aynì). Șadrâ melihat supremacy eksistensi daripada esensi. ${ }^{41}$ Wujud abstrak dalam bentuk "yang esensial" hanyalah ada dalam konsep yang berasal dari wujud-wujud yang konkret, yaitu suatu konsepsi umum yang diandaikan sebagai "esensi” (mâhiyah) wujud-wujud tersebut.

Pandangan Șadrâ ini berbeda dengan Suhrawardî dalam filsafat iluminasi. Menurut Suhrawardî, apa yang disebut dengan "wujud" dalam pengertian ke-menjadi-an (al-ḅusûh) atau ketertubuhan dalam wujud yang konkret tidaklah mungkin terjadi, sebab jika proses kemenjadi-an adalah wujud itu sendiri, maka setiap yang ada mempunyai wujud sendiri. Rangkaian wujud yang tanpa henti semacam itu mustahil terjadi, karena apa yang disebut dengan wujud konkret, juga tak mungkin terjadi. Dengan kata lain, Suhrawardî lebih cenderung melihat wujud hakiki ada pada level konseptual. Sementara itu, wujud konkret hanyalah merupakan epifani, pencerminan dari wujud hakiki yang ada pada level konseptual. ${ }^{42}$ Berbeda dengan Suhrawardî, Mullâ Șadrâ menyatakan yang riil adalah wujud, sementara esensi adalah abstraksi mental. Baginya, wujud bukan hanya lebih prinsipil atau sekadar fondasi bagi seluruh realitas, namun ia adalah realitas. ${ }^{43}$

Filsafat wujud Șadrâ berdiri di atas tiga prinsip dasar yang sangat fundamental. Dengan memahami ketiga prinsip ini, diharapkan kita akan dengan mudah memahami teori-teori filsafat metafisikanya, baik yang berkaitan dengan kosmologi, epistemologi, dan bahkan teologinya. Ketiga prinsip tersebut adalah sebagai berikut: waḥdat al-

41 Alparsian Acikgenc, Being and Existence in Sadra and Heidegger: A Comparative Ontology (Kuala Lumpur: ISTAC, 1995), 39-81, 91-112, dan 129-152.

42 Hossein Ziai, Subrowardi dan Filsafat Illuminasi: Pencerahan Ilmu Pengetabuan, terj. Afif Muhammad (Bandung: Zaman, 1998), 158-165.

43 Perdebatan yang sangat sengit terjadi antara kaum pengikut asâlat al-mâhiyah yang diwakili oleh Suhrawardî dengan pengikut așâlat al-mujûd yang diwakili oleh Mullâ Șadrâ. Suhrawardî berargumen bahwa wujud, karena kedudukannya sebagai sifat umum segala yang ada, yaitu konsep yang paling umum hanya memiliki realitas sebagai konsep sekunder yang tidak mempuanyai hubungan dengan realitas yang ada. Ia hanyalah konsep dan abstraksi mental semata-mata. Jika,kata Suhrawardî selanjutnya, kita menganggap bahwa wujud sebagai sifat esensi yang sebenarnya, maka esensi, agar memiliki sifat ini, harus ada sebelum wujud. Sebab, apabila kita terima teori itu, maka wujud itu sendiri akan memerlukan wujud lain yang bisa memberinya eksistensi; demikianlah seterusnya sehingga ia tak akan berakhir atau mengalami regresi yang infinite.Lihat Fazlur Rahman, Filsafat Shadra, terj. Munir A. Muin (Bandung: Pustaka, 1995), 35. 
wujûd, tashkîk al-wujûd, dan tashkîk." Doktrin waḥdat al-wujûd dalam filsafat Ṣadrâ ini melihat pada realitas wujud mulai dari wâjỉ al-wujûd sampai pada mumkin al-wujûd yang beraneka ragam dan bervariasi, akhirnya melahirkan doktrin lain yang dikenal dengan istilah tashkîk al-wnjûd atau gradasi wujud. Setiap tingkat wujud yang lebih tinggi mengandung semua realitas yang termanifes pada tingkat bawahnya. Di sini Șadrâ mendasarkan diri pada doktrin Suhrawardian tentang diferensiasi (pembedaan) dan gradasi. ${ }^{45}$

Wujud adalah seperti cahaya tersebut dalam arti bahwa ia memiliki derajat intensitas, walaupun sebagai realitas tunggal. Berdasarkan doktrin tashkîk al-wujûd ini, Mullâ Șadrâ menolak keberadaan monisme eksistensial, yang semula diakuinya. Șadrâ mengritik para sufi yang mengakui bahwa wujud hanya menunjukkan satu individu, yaitu Tuhan dan keberadaan dari mâhiyah-mâhiyah sebagai realitas yang positif. Menurut para sufi, wujud adalah suatu individu yang tunggal. ${ }^{46}$ Dari kedua doktrin di atas Șadrâ sampai pada teorinya yang paling orisinil yaitu konsep asâlat al-wujûd. Asâlat al-wujûd berarti wujud adalah prinsip dari segala mawjûd-mawjû̀d yang ada. Lawannya adalah asâlat al-mâhiyah yang dianggapnya bahwa mâhiyah hanyalah wujud dari asumsi pikiran. ${ }^{47}$

${ }^{44}$ Filsafat metafisika Ṣadrâ secara umum bertumpu pada tiga teori yaitu kesatuan wujud (waḥdat al-wnjûd), keutamaan wujud (așâlat al-wnjûd), gerak substansial (alb̧arakah al-jawharîah) dan kemanunggalan yang mengetahui dan diketahui (ittihâad alâqil wa ma'qû́). Filsafat ini berusaha menjembatani antara paradigma rasional empiristik dengan spiritual-mistik. Oleh karena itu, titik tolak dari seluruh bangunan filsafat Isfahan ini adalah konsep Ada (wujud). Jadi objek material filsafat ini yang paling pokok adalah Being atau Ada. Lihat Sayyed Hossein Nasr, "Theology, Philosopy, and Sprituality", dalam Seyyed Hossein Nasr (ed.), Islamic Spirituality: Manifestation (New York: Crossroad Publishing Company, 1997), 76-83.

45 Ibid., 916-917.

46 Ibid., 917.

47 Sebenarnya gagasan Șadrâ ini merupakan gagasan yang diikuti dari gurunya-Mir Damad di awal-awal menggeluti pemikiran filsafat metafisikanya. Mir Damad berpendapat bahwa yang mendasar dan real dari wujud dan esensi adalah esensi. Pendapat ini dikenal dengan nama asâlat al-mâhiyah. Setelah sekian waktu dan mencapai kesimpulan lain, Șadrâ berubah pikiran tentang ihwal mujûd dan esensi. Baginya yang tepat adalah meyakini bahwa kemendasaran hanya pada wujud saja, bukan pada esensi. Akhirnya, ia pun memformulasikan sebuah gagasan baru sekaligus argumentatif tentang kemendasaran wujud, yang populer dengan nama așalat al-wujûd. Lihat Murtadha Muthahari, Pengantar Pemikiran Șadrâ, terj. Tim Penerjemah Mizan (Bandung: Mizan, 2002), 82. 
Konsep asâlat al-wujûd Șadrâ merupakan kritikan terhadap konsep asâlat al-mâhiyah gurunya, Mir Damad. Șadrâ tidak berhenti sampai di situ. Dengan menolak keragaman hakiki antar-hakikat individu wujud tersebut merupakan kelanjutan dari episode berikutnya. Dari serial kefilsafatannya, Șadrâ melakukan lompatan besar dengan mengembalikan hukum gradasi, yang semula diterapkan oleh Suhrawardî, sebagai pendukung konsep kemendasaran esensi, kepada hakikat wujud. Gradasi wujud tidak hanya membalik anggapan terhadap alSuhrawardî, tetapi juga menolak keragaman hakiki dari kaum paripatetik. Bila dilacak lebih jauh, bangunan dokrin Șadrâ terbagi menjadi tiga bagian mendasar, yaitu pertama, filsafat peripatetik Muslim terutama Ibn Sînâ. Lewatnya, ia mengambil filsafat Aristoteles dan beberapa doktrin filsafat Plotinus. Kedua, teosofi ishrâq $\hat{\imath}$ Suhrawardî dan beberapa komentatornya seperti Quțb al-Dîn alShirâzî dan Jalâl al-Dîn al-Dîwanî. Ketiga, doktrin-doktrin gnosis Ibn 'Arabî dan beberapa ekspositor seperti Ṣadr al-Dîn al-Qunawî, 'Ayn alQuḍât al-Ḥamdânî dan Maḥmûd Shabistâr. Keempat, wahyu Islam, khususnya ajaran-ajaran khusus dari Nabi dan imam-imam Shî́ah dalam bagian-bagian Nabj al-Balâghah. Doktrin ajaran Șadrâ berkisar pada wujud dan beberapa polarisasi, esensi gerak atau kejadian dan perubahan substansi alam (dunia), pengetahuan dan hubungan antara yang mengetahui dan yang diketahui, serta jiwa, generasi (tanâsul, tawallud), perfeksi (muntahâ al-itgân), dan berakhir pada resurrection (alamwât, al-ba'th, al-nashr). ${ }^{48}$

Pemikiran Șadrâ tentang wujud senada dengan pemikiran Being and Time-nya Heidegger. Bahasan wujud Șadra cenderung dikotomis, baik antara wujud dan mâhiyah maupun kedudukan subjek-objek. Pada Șadrâ, pemikiran eksistensialismenya lebih pada gnostik atau 'irfân dengan menempatkan subjek pada Tuhan dan objek pada makhluk. Heidegger lebih pada ontologis semata dengan menghilangkan dikotomi subjek-objek sebagaimana pada Șadrâ dan para filsuf Yunani. Bagi Heidegger, subjek dan objek masih berada dalam dunia atau berada dalam waktu. Karena subjek dan objek itu masih berada dalam dunia, maka Heidegger memberikan istilah being pada subjek dan objek tersebut. Di sinilah perbedaan yang prinsip keduanya. ${ }^{49}$

\footnotetext{
48 M.M. Sharif, a History of Mulsim Philosophy, Vol. 1 (Lahore: Pakistan Philosophical Congress, 1963), 942.

49 Acikgenc, Being and Existence, 91-112 dan 129-152.
} 
Berbeda dengan pemikiran para filsuf Muslim tentang being mulai dari Ibn Sînâ dan al-Fârâbî sebagai kelompok filsuf peripatetik, teosofi Ishrâqî Suhrawardî maupun filsuf iluminisme Șadrâ yang membahas being pada dimensi onto-teologi, Mohammad Iqbal menekankan pada metafisika dan anthropological philosophy. Iqbal lebih menekankan being pada dimensi yang lebih konkret, yaitu ego (khudi). Pada tataran onto-teologi, Iqbal hampir senada dengan para filsuf peripatetik, filsuf iluminisme maupun teosofi Ishrâq $\hat{\imath}$, yang menganggap bahwa sesungguhnya yang benar-benar ada adalah wujud Mutlak (absolut being) yaitu Tuhan.

Khudi (ego) merupakan konsep Iqbal tentang filsafat manusia Menurut Iqbal setiap partikel materi adalah individu. Setiap atom bagaimanapun rendahnya dalam skala wujud adalah ego. ${ }^{50}$ Materi adalah sekelompok ego yang berderajat rendah. ${ }^{51}$ Dalam setiap zarrah bermukim kekuatan khudi. ${ }^{52}$ Jadi bisa dikatakan bahwa kbudi adalah hakikat wujud. Tidak mengherankan jika suatu saat Wahid Akhtar pernah menuduh Iqbal sebagai penganut panpsikisme, suatu pandangan yang meyakini bahwa segala realitas bersifat psikis, atau segala benda mempunyai jiwa.

Dalam menjelaskan makna khudi, Iqbal membaginya dalam dua pengertian, yaitu secara metafisik dan etik. Kata khudi secara metafisik digunakan dalam pengertian manusia konkret atau autentik yang tidak dapat dijelaskan, yang menjadi basis dari keunikan masing-masing individu. ${ }^{54}$ Khudi dalam pengertian etik ini sebagai penegasan dan penguatan diri. ${ }^{55}$ Pemikiran filsafat antropologi Iqbal menekankan pada aspek keberadaan (being) manusia. Iqbal dapat dikatakan sebagai seorang filsuf eksistensialisme Islam, karena pemikirannya tentang Ego menitik beratkan pada keberadaan manusia dalam hubungannya dengan Tuhan dan alam. Sebagai seorang eksistensialis, pemikiran Iqbal banyak mempunyai persamaan dengan pemikiran filsuf eksistensialis khususnya Sorenz Kierkegaard di dunia Barat. Keduanya

\footnotetext{
${ }^{50}$ Muhammad Iqbal, The Recontruction of Religion Thought in Islam (New Delhi: Kitab Bhavan, 1981), 71.

51 Ibid., 106.

52 Muhammad Iqbal, Asrar-i Khudi: Rahasia-rahasia Pribadi, terj. Bahrum Rangkuti (Jakarta: Bulan Bintang, 1976), 119.

${ }^{54}$ Syed Abdul Vahid, Thought and Reflections of Iqbal (Lahore: SH. Muhammad Ashraf, 1973), 93.

${ }^{55}$ Ibid., 244.
} 
sama-sama melihat adanya aspek spiritualitas tentang eksistensi manusia. $^{56}$

Filsafat eksistensialisme Iqbal dilatari oleh suasana masyarakat Islam sekitarnya, di mana masyarakat pada waktu itu sudah berubah dari ajaran-ajaran yang asasi. Hal ini dibuktikan oleh Iqbal bahwa masyarakat Islam sudah jatuh ke tangan Barat, di mana peradabanperadaban Barat sudah mendominasi dunia Islam, sehingga manusia kehilangan jati dirinya sebagai manusia di hadapan Tuhan-Nya. ${ }^{57}$ Menurutnya aktivitas ego pada dasarnya berupa aktivitas kehendak seperti tindakan, harapan dan keinginan, bukan semata-mata berpikir seperti yang dikemukakan oleh Descartes. Manusia yang menolak aktivitas ego berarti menolak hidup. Bergson dan Nietzsche mengartikan kehendak kreatif sebagai chaotis, buta, dan tanpa tujuan. Iqbal menegasi pandangan tersebut dengan mengatakan kehendak kreatif adalah sesuatu yang bertujuan, diri selalu bergerak ke satu arah. Meskipun demikian Iqbal mengemukakan tujuan tersebut bukan ditetapkan oleh hukum sejarah maupun takdir sebagai pre conceived plan dari Tuhan.

\section{Penutup}

Problematika being dalam tradisi filsafat lebih berorientasi pada autentisitas dan historisitas manusia yang ada dalam dunia. Konsep

\footnotetext{
${ }^{56}$ Eksistensialisme Iqbal didasarkan pada tradisi Islam dengan titik tekan pada alQur'ân sebagai sumber referensi yang disebabkan adanya pandangan yang menyimpang dalam pemikiran Islam tentang Diri Tuhan dalam hubungannya dengan manusia dan alam. Sedangkan pemikiran ekistensialisme Keirkegaard dipengaruhi oleh tradisi filsafat Barat waktu itu yang menuntut Keirkegaard hadir memberikan sebuah kritikan pedas terhadap pemikiran Hegel, idealisme, materialisme yang muncul di waktu itu. Filsafat Eksistensialisme Soren Kierkegaard merupakan bentuk protes (kritik) atas teori-teori sebelumnya yaitu aliran idealisme dan aliran Materialisme. Sikap protes ini tertuju pada rasionalisme Yunani atau tradisi klasik dari filsafat yang ada dalam diri Plato yang terus dikembangkan oleh Hegel. Lebih jauh tentang serangan eksistensialis terhadap Hegelian. Disamping itu, filsafat eksistensialisme juga bereaksi terhadap filsafat Idealisme. Idealisme juga merupakan pandangan yang ekstrem tentang manusia dan hidup manusia. Dalam hal ini Idealisme memandang bahwa aspek kesadaran dan pikiran adalah keseluruhan dari manusia. Manusia itu adalah sesuatu yang sadar akan dirinya sendiri, sesuatu yang berpikir. Aspek inilah yang dilebih-lebihkan oleh Idealisme, sehingga dalam diri manusia tidak ada barang lain, kecuali pikiran. Robert C. Solomon, From Rationalism to Existentialism (USA: Harper dan Row, 1972), 77.

${ }^{57}$ Untuk mengetahui lebih lanjut puisi-puisi Iqbal bisa dilihat dalam Muhammad Iqbal, Asrar'i Khudi. Lihat juga dalam Albiruni, Maker's of Pakistan and Modern Muslim India (Lahore: Kasmir Bazaar, 1950), 175.
} 
being bagi para filsuf eksistensialis saling melengkapi satu sama lainnya. Antara Sarte, Heidegger maupun Gabriel Marcel sama-sama menekankan pada cara manusia ber-ada. Keberadaan manusia dipandang secara integral sebagai makhluk yang ada dan sadar akan keberadannya yang diistilahkan secara berbeda. Cara ber-ada dan sadar akan ber-adanya diistilahkan sebagai being for itself yang dibedakan dengan being in itself oleh Sartre. Heidegger memandang cara ber-ada manusia sebagai keterlemparan yang mempunyai pemaknaan yang sama dengan being in itself-nya Sarte. Keterlemparan ini menyebabkan manusia ada dalam dunia (being in the world) yang terjebak dengan faktisitas melalui kemewaktuan, sehingga manusia menjadi makhluk yang mendunia.

Makhluk yang mendunia menunjukkan manusia hadir bersama dengan benda-benda dunia, sehingga manusia hadir dengan ada yang mendaging (etre in carne). Di sinilah manusia oleh Marcel diidentifikasi sebagai Tubuh karena ada yang mendaging, pada sisi lainnya tubuh dianggap sebagai milik manusia. Manusia oleh Marcel dianggap mempunyai atau adalah tubuh. Manusia "ada"-lah tubuh mempunyai pemaknaan yang sama dengan being in itself Sartre. Sedangkan manusia mempunyai tubuh lebih dekat pemaknaannya dengan ada dalam dunianya Heidegger. Pemaknaan tentang being bagi eksistensialisme menekankan pada citra manusia yang autentik sekaligus historis.

Konsep being bagi para filsuf Muslim berkaitan dengan wujud, baik wujud mutlak (wâjib al-mujûd) maupun wujud terbatas (mumkin alwujûd). Konsep ini dibahas oleh Suhrawardî yang mengaitkan wujud dengan cahaya ilahi sebagai wâjïb al-wujû̀d. Sadra memandang wujud mempunyai kesamaan dengan konsep gagasan Heidegger tentang being baik secara ontis, ontos maupun ontologis. Sadra juga senada dengan Sartre yang menganggap bahwa eksistensi mendahului esensi dengan menekankan pada wujud konkret sebagai eksistensi yang mendahului wujud abstrak yang disebut sebagai esensi. Konsep being dipertegas sebagai wujud sejati oleh Iqbal dengan istilah khudi atau ego. Melalui ego atau khudi inilah manusia bisa kreatif dan bebas menentukan otonomi eksistensinya.

\section{Daftar Rujukan}

Acikgenc, Alparsian. Being and Existence in Sadra and Heidegger: A Comparative Ontology. Kuala Lumpur: ISTAC, 1995.

Adian, Donny Gahral. Martin Heidegger. Jakarta: Teraju, 2003. 
Albiruni. Maker's of Pakistan and Modern Muslim India. Lahore: Kasmir Bazaar, 1950.

Aune, Bruce. Metaphysics the Elements. London: University of Minnesota Press, 1998.

Blackman, H.J. Six Existentialist Thinkers. London: Routledge dan Kegan Paul, 1952.

Buren, John Van. Martin Heidegger: From the Earliest Essays to Being and Time and Beyond. New York: State University of New York Press, 1993.

Fahry, Majid. Sejarah Filsafat Islam: Sebuah Peta Kronologis. Bandung: Mizan, 2001.

Hadiwijono, Harun. Sari Sejarah Filsafat Barat 2. Yogyakarta: Kanisius, 2002.

Hardiman, F. Budi. Heidegger dan Mistik Keseharian: Suatu Pengantar Meniju Sein und Zeit. Jakarta: KPG Kepustakan Populer Gramedia, 2003.

Huijbers, Theo. Manusia Merenungkan Dirinya. Yogyakarta: Kanisius, 1987.

Iqbal, Muhammad. Asrar'i Khudi: Rahasia-Rahasia Pribadi, terj. Bahrum Rangkuti. Jakarta: Bulan Bintang, 1976.

Iqbal, Muhammad. The Recontruction of Religion Thought in Islam. New Delhi: Kitab Bhavan, 1981.

Ja'far, Suhermanto. Orientasi Baru Filsafat Manusia menurut Islam. Surabaya: LP2M UINSA, 2014.

Kaufmann, Walter. Existentialism from Dostoevsky to Sartre. New York: Meridian, 1975.

Knasas, John FX. Being and Some Twentieth-century Thomists. New York: Fordham University Press, 2003.

Langiulli, Nino. The Existentialist Tradition. USA: Yhe Anchor Books, 1971.

Leksono-Supeli, Karlina. Aku dalam Semesta: Suatu Kajian Filsafat atas Hubungan Subjek-Objek di dalam Kosmologi. Disertasi--Pascasarjana Universitas Indonesia Jakarta, 1994.

Luijpen, WA. Existential Phenomenology. New York: Duquesne Univ. Press, 1960.

Macquarrie, John. Martin Heidegger. London: Lutterworth Press, 1980.

Marcel, Gabriel. Being and Having, terj. Katharine Farrer. Glasglow: University Press, 1949. 
-----. The Mystery of Being Volume I: Reflection and Mystery. London: The Harvill Press, 1950.

----. The Mystery of Being Volume II: Faith and Reality. London: The Harvill Press, 1951.

Misiak, Henryk., dan Sexton, Virginia Staudt. Psikologi Fenomenologi, Eksistensial, dan Humanistik. Bandung: Refika Aditama, 2005.

Muthahari, Murtadha. Pengantar Pemikiran Sadrâ, terj. Tim Penerjemah Mizan. Bandung: Mizan, 2002.

Nasr, Sayyed Hosein., dan Leaman, Oliver (eds.). Ensiklopedi Tematis Filsafat Islam, terj. Tim Penerjemah Mizan. Bandung: Mizan, 2003.

Nasr, Sayyed Hossein. "Theology, Philosopy, and Sprituality", dalam Seyyed Hossein Nasr (ed.), Islamic Spirituality: Manifestation. New York: Crossroad Publishing Company, 1997.

Natanson, Maurice. Phenomenology and the Social Sciences. London: North-Western: University Press, 1973.

Partenie, Catalin., dan Rockmore, Tom (eds.). Heidegger and Plato toward Dialogue. Evanston, Illinois: Northwestern University Press, 2003.

Preus, Anthony. Historical Dictionary of Ancient Greek Philosophy. Lanham: Scarecow Press, 2007.

Rahman, Fazlur. Filsafat Shadra, terj. Munir A. Muin. Bandung: Pustaka, 1995.

Rapar, Jan Hendrik. Pengantar Filsafat. Yogyakarta: Kanisius, 1996.

Sartre, Jean-Paul. Being and Nothingness. New York: Simon dan Schuster, 1992.

-----. Existentialism and Human Emotion. New York: Castle, 1948.

Schmid, Hans Bernhard. Plural Action Essays in Philosophy and Social Science. London New York: Springer Dordrecht Heidelberg, 2008.

Schumacher, E.F. Keluar dari Kemelut: Sebuah Peta Pemikiran Baru. Jakarta: LP3ES, 1988.

Sharif, M.M. A History of Mulsim Philosophy, Vol. 1. Lahore: Pakistan Philosophical Congress, 1963.

Solomon, Robert C. From Rationalism to Existentialism. USA: Harper dan Row, 1972.

Vahid, Syed Abdul. Thought and Reflections of Iqbal. Lahore: SH. Muhammad Ashraf, 1973.

Warren, James. Facing Death: Epicurus and his Critics. Oxford: Clarendon Press, 2004.

Ziai, Hossein. Subrowardi dan Filsafat Illuminasi: Pencerahan Ilmu Pengetahuan, terj. Afif Muhammad. Bandung: Zaman, 1998. 